\title{
Memorias sociojurídicas de Medellín y Antioquia. Análisis del relato "negro" como evidencia de fuente real del derecho"
}

\section{Sociojuridical memories of Medellin and Antioqu a. An analysis of the "black" story as evidence of : source of the Law}

Recibido: 10 de diciembre de 2016 - Revisado: 13 de mayo de 2017 - Aceptado: 09 de julio de 2017.

\section{Laura Bayer Yepes}

\section{Resumen}

El presente artículo muestra una aproximación sociojurídica a los contextos histó. os de la producción literaria colombiana, especialmente, los escenar os que se han tomado en los últimos 30 años como telón de la novela "negra" o de crímer en Medellí 1 y Antioquia. Esto con el fin de ejemplificar, a partir de cuatro chras clave la narrat va antioqueña,

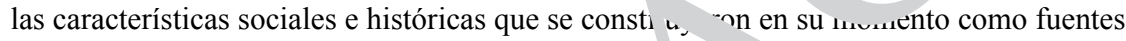
reales o materiales del derecho en Colombia. Con ur a inv. 'ación cualitativa basada en

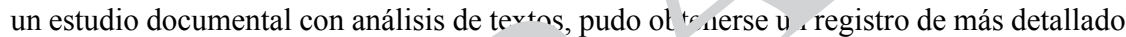
de cómo las situaciones particulare son e unto de artida de las leyes y disertaciones jurídicas que tienen vigencia hov.

\section{Palabras clave}

Derecho, fuentes reales del d 'cho, literat , análisis sociojurídico, novela negra.

\begin{abstract}
This article si vs a so ial-legal ap roach to the historical contexts of Colombian literary production, espc ${ }^{\prime} \mathrm{y}$, the sc enes that have been taken over the past 30 years as a curtain on th $\quad r$ " or cr. e nove' in Medellin and Antioquia. This, in order to exemplify from fo key orks of $t_{1}$.ntioquia narrative, the social and historical characteristics that wer con inited at the time as real or material sources of Law in Colombia. This can be att. 'ed by w..ducting a qualitative research based on a documentary study with text analysis, more detailed record of how particular situations are the starting point of the Law and I gal dissertations that are valid today.
\end{abstract}

\section{Keywords}

Law, real sources of Law, literature, socio-legal analysis, crime novel.
${ }^{1}$ Artículo generado a partir del trabajo de grado: "La novela negra en Medellín: historia, literatura y periodismo, de 1990 a 2014" para aspirar al título de Comunicador social - periodista de la Universidad Pontificia Bolivariana. ${ }^{2}$ Corporación Universitaria Americana, Medellín, Colombia. Correo electrónico: laurabayercomunicacion@ gmail.com

Para citar este artículo use: Bayer, L. (2018). Memorias sociojurídicas de Medellín y Antioquia. Análisis del relato "negro" como evidencia de fuente real del derecho. Revista Civilizar, 18(34), 179-188. 